\title{
Market Power in the Czech Banking Sector
}

\author{
Repková Iveta
}

\begin{abstract}
This paper estimates the market power in the Czech banking sector during the period 2000 2010. In order to measure the degree of market power in the Czech banking sector, the authors used the Lerner index, the Herfindahl-Hirschman index and the concentration ratio. The Lerner index is applied to data from 15 banks, which covers about $90 \%$ of the Czech banking market. The paper describes the theoretical framework of the competition, especially the Lerner index and measures of concentration. Authors also compute separate Lerner index for the Czech credit market and the Czech deposit market. The estimations of the Lerner index do not confirm either monopoly or perfect competition structure in the Czech banking sector over the period analyzed. The competition decreased in the period 2000-2005 which was affected by the decrease in the price of funds and capital. However, the competition increased in the period 2005-2010, and it was influenced by the increase in the price of funds and capital. From the value obtained from the Lerner index, it was found that the lowest competition was in the deposit market.
\end{abstract}

Key words: market power, Lerner index, Herfindabl-Hirschman index, competition, Czech banking sector, total assets, credit market, deposit market

\section{INTRODUCTION}

Market power, depicted by the Lerner Index, is measured as a relative mark-up of price over marginal cost divided by price (Lerner, 1934). Coccorese (2009) argues that the Lerner index is a true reflection of the banks' degree of market power because it represents the behavioural departure from monopoly and perfect competition. Market power is especially prevalent in industries dominated by a few large firms, which serve as market leaders through collusive conduct. Measuring the degree of competition has always been a problem in economics. Previous literature has shown that there have been a number of ways of observing and measuring bank competition. It is generally accepted that these methods can be categorised as structural and non-structural approaches.

Several empirical studies examined the competition in the Czech banking market. Pruteanu Podpiera et al. (2007) applied Lerner index in the Czech credit market in period 1995-2005. They found a decrease in competition between the periods 1995-1998 and 1999-2000 followed by an increase lasting until 2002. The period 2003-2004 saw a decrease in competition with a slight revival in 2005. Other empirical analysis used Panzar-Rosse model for estimating competitive conditions in the Czech banking sector. Staikouras and Koutsomanoli Fillipaki (2006) indicated the monopolistic competition in period 1998-2002. Bikker et al. (2007), Bikker and Spierdijk (2008) and Bikker et al. (2009) were identifying the monopolistic competition during the period 1986-2004. 
The aim of this paper is to estimate the market power in the Czech banking sector during the period 2000-2010. To measure of the market power is using the Lerner index, which is applied on data from the Czech banks covered about $90 \%$ of the banking sector. We compute the Lerner index for the Czech banking sector and we also estimate the Lerner index separately for the Czech credit market as well as for deposit market. In addition to these more accurate measures of market power, we also examine standard concentration variable Herfindahl-Hirschman index (HHI) and the concentration ratio. The structure of the paper is follow. First part describes the empirical literature about competition in the banking industry. Next, the Czech banking sector is presented and we also describe the theoretical methodology, especially the Lerner index. In results the estimation output is shown, we compute the Herfindahl-Hirschman index, the concentration ratio and the Lerner index for the Czech banking sector.

\section{METHODOLOGY AND DATA}

We used the dataset of 15 Czech banks, which covered about $90 \%$ of the Czech banking sector. Due to entry and mergers, the sample is an unbalanced panel of 150 observations of nonconsolidated banking firms. The bank-level financial data are obtained from the annual reports of individual banks and the BankScope database. In the paper we apply the Lerner index for testing the market power in the Czech banking industry during the period 2000-2010.

For the analysis, we compute the Lerner indexe for the Czech banking sector. We compute the Lerner index to get an individual measure of competition for each year of our time sample. The Lerner index is used to measure the evolution of market power. In addition to these more accurate measures of market power, we also examine standard concentration variable Herfindahl-Hirschman index (HHI).

\subsection{Herfindahl-Hirschman index}

The Herfindahl-Hirschman index is the most widely treated summary measure of concentration in the theoretical literature and often serves as a benchmark for the evaluation of other concentration indices. Bikker and Haaf (2000) defined HHI as the sum of the squares of the bank sizes measured as market shares. Often called the full-information index because it captures features of the entire distribution of bank sizes, it takes the form:

$$
H H I=\sum_{k=1}^{n}\left(\frac{q_{k}}{Q}\right)^{2}=\sum_{k=1}^{n} r_{k}^{2}
$$

where $n$ is the number of banks in the banking sector,

$q_{k}$ is the volume of the output of bank $\mathrm{k}, \mathrm{k}=1,2, \ldots, \mathrm{n}$,

$Q$ is the volume of the output of the banking sector,

$r_{k}$ is the share of the output of the bank $\mathrm{k}$ to the output of the banking sector.

The HHI stresses the importance of larger banks by assigning them a greater weight than smaller banks, and it incorporates each bank individually, so that arbitrary cut-offs and insensitivity to the share distribution are avoided. The HHI index ranges between $1 / \mathrm{n}$ and 1 , reaching its lowest value, the reciprocal of the number of banks, when all banks in a market are of equal 
size, and reaching unity in the case of monopoly (in a market with only one bank). Sometimes the value of $\mathrm{HHI}$ is multiplied by 10000 and then $\mathrm{HHI}$ indices in the range below 1000 show a very low concentration, in the range 1000-1800 show a moderate concentration, in the range above 1800 show a very high concentration of the banking system, whereas the index value equal to 10000 shows a full concentration (monopoly).

\subsection{Concentration ratio}

The concentration ratio (CR) shows the degree to which an industry is dominated by a small number of large firms or made up of many small banks. Simplicity and limited data requirements make CR one of the most frequently used measures of concentration in the empirical literature. Summing over the market shares of the $\mathrm{k}$ largest banks in the market, it takes the form:

$C R_{k}=\sum_{i=1}^{k} s_{i}$

CR gives equal emphasis to the $\mathrm{k}$ leading banks, but neglecting the many small banks in the market. There is no rule for the determination of the value of $\mathrm{k}$, so the number of banks included in the concentration index is a rather an arbitrary decision. The concentration ratio may be considered as one point on the concentration curve, and it is a one-dimensional measure ranging between zero and unity. The index approaches zero for an infinite number of equally sized banks and it equals unity if the banks included in the calculation of the concentration ratio make up the entire industry.

\subsection{Lerner index}

Market power (or firms' ability to price above marginal cost) is a powerful concept in economics because, among other things, it illustrates how and whether imperfectly competitive markets depart from the perfect competition benchmark; as such, this concept arises in many economic courses, especially those with a microeconomics focus (Rojas, 2010).

Casu and Girardone (2009) claim that the Lerner index of monopoly power is an indicator of the degree of market power and it is a well established measure of competition in the banking literature. It represents the extent to which market power allows firms to fix a price below marginal cost (MC).

Demirguc-Kunt and Peria (2010) show an alternative way to examine competition in banking is to compute direct measures of market power, since greater market power implies less competition. A frequently used measure of market power in banking is the Lerner index, defined as the difference between output prices and marginal costs (relative to prices).

The Lerner Index is a direct measure of competition because it focuses on the pricing power apparent in the difference between price and marginal cost thereby capturing the degree to which a firm can increase its marginal price beyond marginal cost (Berger et al., 2009).

Theoretically, a key determinant of market power is demand elasticity; a popular measure of such relationship is the Lerner index (Lerner, 1934). A number located in the unit interval that is usually depicted as having an inverse relationship with (the absolute value of) demand 
price elasticity. The Lerner index is appealing because it shows where a firm's market power is located between perfect competition and maximal market power, and the role that demand elasticity plays in determining a firm's mark-up (Rojas, 2010).

Fernandez de Guevara (2005) show the interpretation of the Lerner index as market power is often made too mechanically, as it is necessary to take into account several problems that are posed in the empirical estimation when valuing its significance.

Firstly, the value of the Lerner index is influenced by the criteria followed when more or fewer concepts are included in the calculation of revenue and costs. Thus it is not infrequent to consider only financial revenue and costs and to omit other revenue and trading costs (so that the margin varies and the value of the index changes). When only the traditional intermediation activity of loans-deposits is considered, the model does not consider the banking activity of providing services. The substantial growth in this type of activity in recent years has led to a change in the revenue structure of banking firms; the relative importance of net financial revenue has decreased, and revenue from items other than interest (mainly commissions) has increased.

Secondly, it is general practice not to consider the cost of risk, even though its effect on the profit and loss account of banking systems is on average very important. There are various reasons for the continuance of these practices: the lack of sufficient data, the difficulties of calculation, and in the case of the cost of risk, the problem of its posting in time, as banking risk often appears only at a certain moment of the life of the investments made.

It is important to point out that, although the cost of risk is not included in the estimation of the cost function, this problem is present in two ways: 1) if the cost of risk is not taken into account, the interpretation of the Lerner index as market power may be wrong because it overestimates the margin; and 2) if the cost of risk is only computed when the corresponding provisions are made, its time profile will be skewed, as it can be said that these are costs that were latent in other periods but whose recognition has been delayed. In this last case, the Lerner index is likely to increase in an expanding phase of the cycle (in which there are few problems of bad debt and insolvency) and decrease in a low phase of the cycle (in which bad debt and provisions increase) without affecting market power.

Thirdly, the empirical estimation of separate prices or rates for loans and deposits is not without problems. Thus, in the case of loans the profit and loss account does not give separately the financial income associated with them, as it appears jointly with other financial products (fixed income investments, for example). In the case of deposits, the financial costs are included with those of other liability products (Fernandez de Guevara, 2005).

The Lerner index is a more accurate measure of market power than the standard concentration measures. Berger et al. (2009) claim that the Lerner index is averaged over time for each bank $i$ for inclusion in the regression model. It should be noted that the constructed Lerner index does not capture risk premia in the prices of banks' product and services, breaking down its positive association with the size of monopoly rents. However, it is the only measure of competition that is computed at the bank level. Demirguc-Kunt and Peria (2010) show the advantage of the Lerner index, opposite (against) the Panzar-Rosse (1987) H statistic, is that it is not a long-run equilibrium measure of competition. Also, because of this, the Lerner index can be calculated at each point in time. 
In practice, an important weakness of the Lerner index approach is that available bank balance-sheet data do not correspond to the prices and costs required to calculate the index, so that many debatable choices are needed to proxy prices and costs (Bikker et al., 2007).

The index is defined as the difference between price and marginal cost, divided by price. It is a level indicator of the proportion by which price exceeds marginal cost, and is calculated as:

$L I_{i t}=\frac{P_{i t}-M C_{i t}}{P_{i t}}$

where $P_{i t}$ is the price of banking outputs for bank i at time $t$, $M C_{i t}$ is the marginal costs for bank i at time t.

The resulting $L I_{i t}$ is averaged over the period under study for each bank $i$. Pit is the price of total assets proxied by the ratio of total revenues (interest and noninterest income) to total assets for bank $i$ at time t. $M C_{i t}$ is derived from the translog cost function Eq. (4).

Following the approach in Fernandez de Guevara et al. (2005), Berger et al. (2009), DemirgucKunt and Peria (2010) or Fungáčová et al. (2010), who proxy banking production by total assets, $\mathrm{P}$ is calculated as ratio of total bank revenues to total assets. $M C$ is estimated on the basis of a translog cost function with one output (total assets) and three input prices (price of labor, price of physical capital, and price of borrowed funds). Symmetry and linear homogeneity restrictions in input prices are imposed. The cost function is specified as follows:

$\ln T C=\alpha_{0}+\alpha_{1} \ln y+\frac{1}{2} \alpha_{2}(\ln y)^{2}+\sum_{j=1}^{3} \beta_{j} \ln w_{j}+\sum_{j=1}^{3} \sum_{k=1}^{3} \beta_{j k} \ln w_{j} \ln w_{k}+$

$+\sum_{j=1}^{3} \gamma_{j} \ln y \ln w_{j}+\varepsilon$

where $T C$ denotes total costs,

$y$ total assets,

$w_{j k}\left(w_{1}, w_{2}\right.$ and $\left.w_{3}\right)$ indicate three input prices (i.e. labor, capital and funds).

$W_{1}$ indicate the price of labor, which is the ratio of personnel expenses to total assets, $w_{2}$ is the price of physical capital, which is the ratio of other non-interest expenses to fixed assets and $w_{3}$ is the price of borrowed funds, which is the ratio of interest expenses to total funds.

Total cost is the sum of personnel expenses, other non-interest expenses and interest expenses. The indices for each bank have been excluded from the equation for the sake of simplicity. The estimated coefficients of the cost function are then used for computing the marginal cost. Indeed, as marginal cost is the derivative of total cost to output, it can be derived that the derivative of the logarithm of total cost to logarithm of output is the ratio of marginal cost to total cost multiplied by output. As a consequence, marginal cost is equal to the product of the derivative of the logarithm of total cost to output multiplied by the ratio of total cost to output. The derivative of the logarithm of the total cost with respect to the logarithm of output is computed using the cost function specified in Eq. (4). The marginal cost is based on the estimation of the cost function. We estimate a translog cost function with one output and three input prices. 
The estimated coefficients of the cost function are then used to compute the marginal cost (MC):

$M C=\frac{T C}{y}\left(\alpha_{1}+\alpha_{2} \ln y+\sum_{j=1}^{3} \gamma_{j} \ln w_{j}\right)$

Once marginal cost is estimated and price of output computed, we can calculate Lerner index for each bank and obtain a direct measure of bank competition. It should be noted that the constructed Lerner index does not capture risk premia in the prices of banks' product and services, breaking down its positive association with the size of monopoly rents. However, it is the only measure of competition that is computed at the bank level (Berger et al., 2009).

The Lerner index ranges between zero and one. When P = MC, the Lerner index is zero and the firm has no pricing power. A Lerner index closer to one indicates the higher mark-up of price over marginal costs and hence market power for the firm (Ariss, 2010). In general, LI $=0$ it indicates perfect competition, while LI $=1$ indicates monopoly. The Lerner index is an inverse measure of competition, i.e., a greater Lerner index means lower competition (Pruteanu-Podpiera et al., 2007).

\section{ESTIMATION OUTPUT AND DISCUSSION}

For the analysis, we calculate the Lerner index for the Czech banking sector. We also compute the Lerner index for the Czech credit market as well as for the deposit market. In addition to these more accurate measures of the market power, we also examine standard concentration variable the Herfindahl-Hirschman index (HHI). First, descriptive statistics of individual variables are presented in Table 1.

Tab. 1 - Descriptive statistics. Source: Authors' calculation

\begin{tabular}{|l|l|l|l|l|l|l|l|l|}
\hline & $\mathrm{y}$ & LOANS & DEPOSITS & TC & $\mathrm{P}$ & w1 & w2 & w3 \\
\hline Mean & 171438.8 & 77901.16 & 122545.5 & 9154.677 & .0652 & 0.7663 & 2.9681 & 0.0263 \\
\hline Median & 56572.80 & 29827.00 & 41410.80 & 2457.400 & 0.0597 & 0.6912 & 1.3933 & 0.0202 \\
\hline Maximum & 788177.0 & 422468.0 & 568199.0 & 107533.2 & 0.2618 & 2.2622 & 79.109 & 0.1225 \\
\hline Minimum & 930.70 & 107.10 & 332.80 & 36.00 & 0.0226 & 0.2569 & 0.2569 & 0.0028 \\
\hline Std. Dev. & 224897.8 & 97299.78 & 163767.0 & 14508.67 & 0.0292 & 0.2994 & 6.5982 & 0.0208 \\
\hline
\end{tabular}

\subsection{Herfindahl-Hirschman index}

First, the Herfindahl-Hirschman index (HHI) is computed and the values of the HHI are presents in Table 3. The HHI is more traditional measures of the degree of market power. Similar to the Lerner index and essentially to all measures of market power commonly used in the literature, the HHI index are also based on a single-product assumption. 


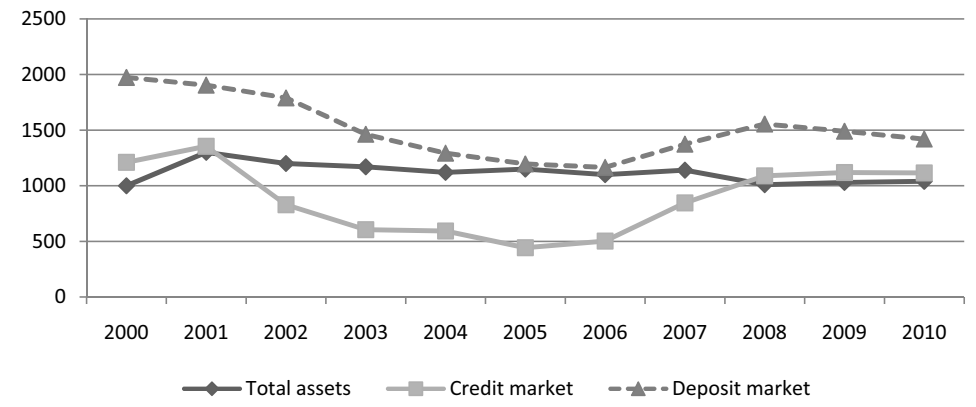

Fig. 1 - Herfindabl-Hirschman index. Source: Author's calculation

In general, the values of HHI show a trend of modest decrease, meaning that market concentration changed appreciably over the sample period (Fig. 1). In 2010, the degree of concentration of the banking sector, as measured by the Herfindahl-Hirschman index, increased to 0.104, while client deposits and client loans showed the opposite trend. The Czech banking market could be described as a moderately concentrated market over the period of 2000-2010. The highest concentration is found in the deposit market, on the other side, the lowest concentration were in the credit market.

\subsection{Concentration ratio}

We use the three largest bank concentration ratio (CR3) which calculated the market concentration of the whole banking sector and also we calculated concentration in credit market and deposit market separately. CR3 of whole banking sector are defined as the ratio of the total assets of the three largest banks to the total assets of all the banks in a given year. Concentration of the credit market is measures as the ratio of the total loans of the three largest banks to total loans. And concentration of the deposit market is calculated as the ratio of the deposits of the three largest banks to total deposits.

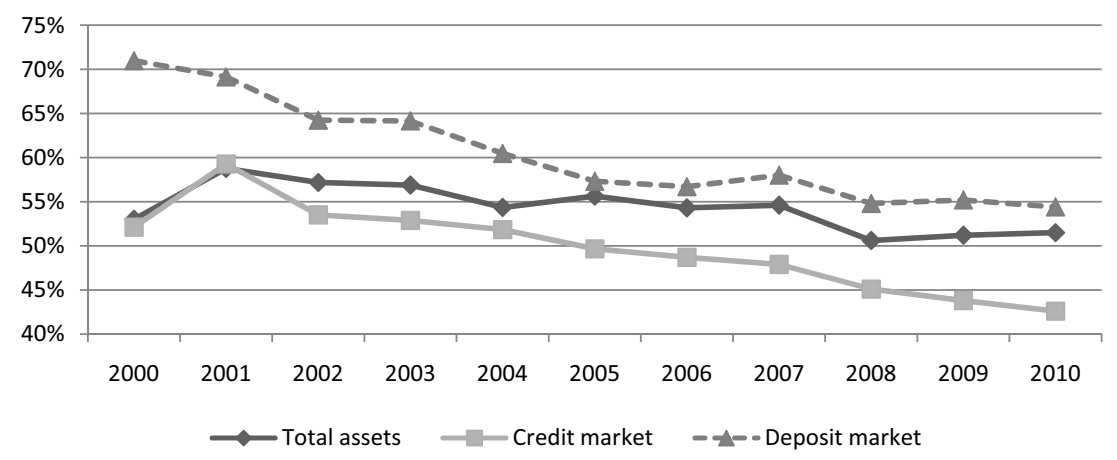

Fig. 2 - Concentration ratio of the three largest banks. Source: Author's calculation 
The values of the CR3 of the total assets, the credit market and the deposit market show a trend of modest decrease (Fig. 2). It indicates that the concentration of the Czech banking sector was decreasing over the analysed period. The Czech banking sector could be described as a moderately concentrated market over the period of 2000-2010.

\subsection{Lerner index}

First, we estimate Eq. (4) and Eq. (5), and then we can calculate the Lerner index as in Eq. (3). The cost function is estimated for each year so as to allow the coefficients of the cost function to evolve over time. The cost function is estimated introducing fixed effects for banks. The results for each year are presented in Table 2. We compute mean and median of the Lerner index. Pruteanu-Podpiera et al. (2007) argues that the Lerner index is an inverse measure of competition, i.e. a greater Lerner index means lower competition. The statistics of Lerner indices per year concern all the Lerner indices of the year for all analysed banks, where the banks have equal weights.

Tab. 2 - Lerner index. Source: Authors' calculation

\begin{tabular}{|c|c|c|c|}
\hline Year & Mean & Median & Std. Dev. \\
\hline 2000 & 0.2437 & 0.3519 & 0.4659 \\
\hline 2001 & 0.3831 & 0.3265 & 0.2261 \\
\hline 2002 & 0.4003 & 0.3729 & 0.1784 \\
\hline 2003 & 0.4735 & 0.4444 & 0.2045 \\
\hline 2004 & 0.3797 & 0.3926 & 0.2172 \\
\hline 2005 & 0.4627 & 0.4845 & 0.1623 \\
\hline 2006 & 0.4216 & 0.3904 & 0.1368 \\
\hline 2007 & 0.4158 & 0.4381 & 0.1562 \\
\hline 2008 & 0.3454 & 0.3641 & 0.1097 \\
\hline 2009 & 0.2076 & 0.1333 & 0.1700 \\
\hline 2010 & 0.5304 & 0.4595 & 0.1341 \\
\hline $2000-2010$ & 0.3704 & 0.3955 & 0.2505 \\
\hline
\end{tabular}

At first sight the results cannot distinguish a clear-cut trend in the evolution of the Lerner index. During the period 2000-2005 the Lerner index increased, signalling a slight decrease in competition. This episode was followed by a decrease in the Lerner index; hence a slight increase in competition, during 2006-2009. In 2010 the value of the Lerner index is also increased, which show decrease in competitive conditions.

Our results is confirmed by Pruteanu-Podpiera et al. (2007) that found the evolution became more regular with a clear increase from 2002 to 2005. They pointed out that the entry of foreign investors in the Czech banking industry, which considerably increased from 1999 with the launching of the privatization of major banks, does not seem to favor a strong increase in banking competition. It led to an increase in competition until 2002, but then the results show a drastic decrease in competition. They argued that as this entry meant a strong change in the ownership of banks. However, they stressed that the empirical literature on banking sectors 
in developed economies concludes in favor of imperfect competition. Therefore, the strong foreign ownership in Czech banks may have favored a process of convergence of banking performance towards the normal functioning of a market economy, even if a strong level of banking competition is not observed.

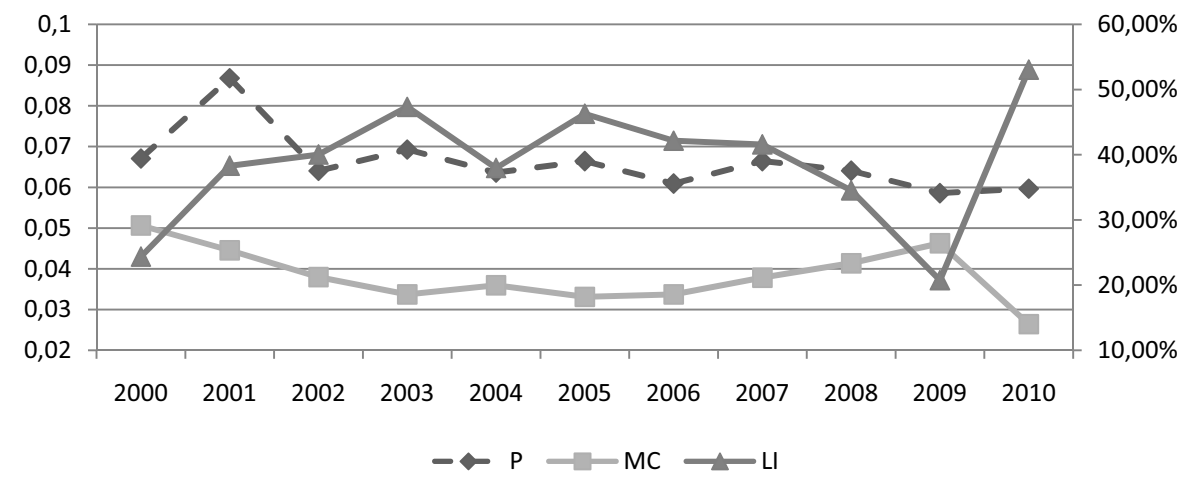

Fig. 3 - Evolution of the output price, the marginal costs and the Lerner index. Source: Author's calculation

Figure 3 shows the evolution of the output price, the marginal cost and the Lerner index of the Czech banking sector. Marginal costs were decreasing during the period 2000-2005 and then marginal costs were increasing during the period 2005-2009, marginal costs were also significantly decreasing in 2010. It can be seen that as a result of the joint evolution of marginal costs, the value of the Lerner index increased from 35.19\% in 2000 to $39.26 \%$ in 2004 and then the value of the Lerner index were decreasing from $48.45 \%$ in 2005 to $45.95 \%$ in 2010 . It can be argued that this evolution of the Lerner index is influenced by decreasing of price of funds and price of capital in period 2000-2004 and then price of funds and capital increased in period 2005-2010.

Thus, we can conclude that the competition in the Czech banking market stands somewhere between the two extremes - monopoly and perfect competition. The competition decreased in the period 2000-2005 which was affected by decreasing of price of funds and capital. And competition increased in the period 2005-2010 which was influenced by increasing of price of funds and capital.

Next, we estimate the Lerner index separately for the Czech credit market and deposit market. The value of the Lerner index computed for the Czech credit market is presented in Table 3.

Tab. 3 - Lerner index of the Czech credit market. Source: Authors' calculation

\begin{tabular}{|c|c|c|c|}
\hline Year & Mean & Median & Std. Dev. \\
\hline 2000 & 0.4438 & 0.5486 & 0.3749 \\
\hline 2001 & 0.5598 & 0.5455 & 0.1979 \\
\hline 2002 & 0.5723 & 0.5530 & 0.1567 \\
\hline 2003 & 0.6165 & 0.6089 & 0.1679 \\
\hline
\end{tabular}




\begin{tabular}{|c|c|c|c|}
\hline 2004 & 0.5430 & 0.5371 & 0.1833 \\
\hline 2005 & 0.5980 & 0.6163 & 0.1433 \\
\hline 2006 & 0.5673 & 0.5457 & 0.1205 \\
\hline 2007 & 0.5650 & 0.5739 & 0.1458 \\
\hline 2008 & 0.5109 & 0.5029 & 0.1105 \\
\hline 2009 & 0.3921 & 0.3289 & 0.1507 \\
\hline 2010 & 0.6742 & 0.6582 & 0.1117 \\
\hline $2000-2010$ & 0.5359 & 0.5479 & 0.2073 \\
\hline
\end{tabular}

The evolution of estimation of the Lerner index in the credit market is similar as the evolution of the Lerner index computed for total assets. During the period 2000-2005 the Lerner index computed for the credit market slightly increased, signalling a slight decrease in competition. This episode was followed by a slight decrease in the Lerner index; hence a slight increase in competition, during 2006-2009. In 2010 the value of the Lerner index is also increased, which show decrease in competitive conditions.

More concretely, the value of the Lerner index increased from $44.38 \%$ in 2000 to $54.30 \%$ in 2004 and then the value of the Lerner index were decreasing from $59.8 \%$ in 2005 to $39.20 \%$ in 2009 and then also the Lerner index increase to $67.42 \%$ in 2010. The mean of the Lerner index computed for the full sample is $53.58 \%$, which do not confirm either monopoly or perfect competition in the Czech credit market.

Tab. 4 - Lerner index of the Czech deposit market. Source: Authors' calculation

\begin{tabular}{|c|c|c|c|}
\hline Year & Mean & Median & Std. Dev. \\
\hline 2000 & 0.5905 & 0.6898 & 0.3112 \\
\hline 2001 & 0.6864 & 0.6959 & 0.1710 \\
\hline 2002 & 0.6930 & 0.6692 & 0.1379 \\
\hline 2003 & 0.7170 & 0.7204 & 0.1443 \\
\hline 2004 & 0.6595 & 0.6482 & 0.1536 \\
\hline 2005 & 0.6955 & 0.7100 & 0.1250 \\
\hline 2006 & 0.6718 & 0.6806 & 0.1049 \\
\hline 2007 & 0.6696 & 0.6776 & 0.1283 \\
\hline 2008 & 0.6255 & 0.6328 & 0.1064 \\
\hline 2009 & 0.5266 & 0.4880 & 0.1259 \\
\hline 2010 & 0.7642 & 0.7355 & 0.0976 \\
\hline $2000-2010$ & 0.6563 & 0.6624 & 0.1706 \\
\hline
\end{tabular}

Table 4 presents the estimation of the market power in the deposit market. The evolution of estimation of the Lerner index in the deposit market is almost constant during the estimated period. During the period 2006-2009 the Lerner index computed for the deposit market slightly decrease, signalling a slight increase in competition. This episode was followed by an increase in the Lerner index; hence a slight decrease in competition in 2010. 


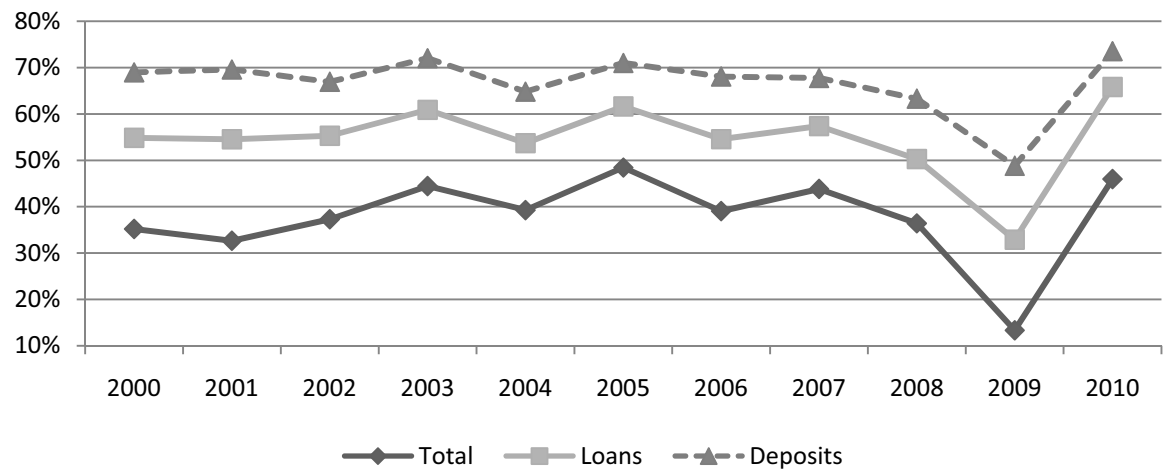

Fig. 4 - The Lerner index of the total assets, the credit and the deposit market. Source: Author's calculation

Figure 4 summarize the evolution of the Lerner index of the total assets, credit market and deposit market. The highest value of the Lerner index is in the deposit market, which signalize the lowest competition in the deposit market. This confirms the value of the HerfindahlHirschman index which shows the deposit market is the most concentrated. The value of the Lerner index significantly decrease in 2009 and then the value of the Lerner index increase in 2010. Values decrease was caused by the slight increasing of marginal costs and also the value of the Lerner index increase was affected by the significantly decreasing of the marginal costs, especially the decrease in input price of funds and also price of capital.

\subsection{Discussion}

The results confirm the argument, that the increases in the HHI generally indicate a loss of pricing power and a decrease in competition, whereas decreases imply the opposite (Chan et al., 2007). HHI was continuously decreasing from 2001 to 2010 and it was found the increasing banking competition in the Czech banking sector. Thus, we can say that the concentration and the market power were decreasing and the banking competition was slightly increasing in the Czech banking sector.

The mean of the Lerner index computed for the full sample is $39.54 \%$, which do not confirm either monopoly or perfect competition. This result is confirmed by e.g. Bikker et al. (2007), Bikker and Spierdijk (2008) and Bikker et al. (2009) who revealed the monopolistic competition until 2004. The most striking finding is the absence of a decreasing trend of the Lerner index in 2005-2009, which mean an increase in banking competition. From 2001 to 2005, the evolution became more regular with a clear increase, which confirms the results which found Pruteanu-Podpiera et al. (2007).

We think that the entry of foreign investors in the Czech banking industry, which considerably increased from 1999 with the launching of the privatization of major banks, does not seem to favor a strong increase in banking competition. Because in the first sub-period 2000-2005, the market power was increasing and the banking competition was decreasing. It is surprising, because this entry meant a strong change in the ownership of banks. However, the empirical literature on banking sectors in developed economies concludes in favor of imperfect competition. As Pruteanu-Podpiera et al. (2007) explained the strong foreign ownership in Czech banks may 
have favored a process of convergence of banking performance towards the normal functioning of a market economy, even if a strong level of banking competition is not observed.

\section{CONCLUSION}

The aim of this paper was to estimate the market power in the Czech banking industry during the period 2000-2010. First, we applied the Herfindahl-Hirschman index and the concentration ratio. The values of the Herfindahl-Hirschman index and concentration ratio show a trend of modest decrease, meaning that market concentration changed appreciably over the sample period. The Czech banking market could be described as a moderately concentrated market over the period of 2000-2010. Next, we used the Lerner index applied on data from the Czech banks covered about $90 \%$ of the banking sector. We came to conclusion that the Lerner index computed for the full sample is $37.04 \%$, which do not confirm either monopoly or perfect competition. In addition, we can identify two sub-periods of divergent development of market competition. Whereas the competition decreased during 2000-2005 it increased during the period 2005-2009. More concretely, mean of the Lerner index for total assets for the first periods is $37.61 \%$ and for the second period is $39.73 \%$. The value of the Lerner index compute for the Czech credit market was 53.59 \% in the period 2000-2010 and the value of the Lerner index compute for the deposit market was $65.63 \%$ for the full sample period. Thus, we can conclude that the Czech banking sector as well as the credit and deposit markets operates between two extremes monopoly and the perfect competition and the lowest competition was estimated in the Czech deposit market. To further research we recommend to apply the Panzar-Rosse model or Bresnahan model to estimate the level of the competition in the Czech banking sector. Those models enable more accurately to estimate the degree of the competition in banking industry.

\section{Acknowledgement}

Research behind this paper was supported by the Student Grant Competition of Silesian University within the project SGS 25/2010 'Financial integration in the EU and its effect on corporate sector'.

\section{References}

1. Ariss, R.T. (2010). Competitive conditions in Islamic and conventional banking: A global perspective. Review of Financial Economics, 19 (3), 101-108. http://dx.doi.org/10.1016/ j.rfe.2010.03.002

2. Bikker, J.A. \& Haaf, K. (2000). Measures of competition and concentration in the banking industry: a review of the literature. De Nederlandsche Bank Research Series Supervision No. 27.

3. Bikker, J.A., Spierdijk, L. \& Finnie, P. (2007). The Impact of Market Structure, Contestability and Institutional Environment on Banking Competition. DNB Working Paper No. 156.

4. Bikker, J.A. (2008). Spierdijk, L. How Banking Competition Changed over Time. DNB Working Paper No. 167.

5. Bikker, J.A., Shaffer, S. \& Spierdijk, L. (2009). Assessing Competition with the Panzar-Rosse Model: The Role of Scale, Costs, and Equilibrium. Utrecht School of Economics Discussion Paper Series No. 27. 
6. Berger, A.N., Klapper, L.F. \& Turk-Ariss, R. (2009). Bank Competition and Financial Stability. Journal of Financial Services Research, 35 (2), 99-118. http://dx.doi.org/10.1007/s10693-0080050-7

7. Casu, B. \& Girardone, C. (2006). Bank Competition, Concentration and Efficiency in the Single European Market. Manchester School, 74 (4), 441า-468. http://dx.doi.org/10.1111/ j.1467-9957.2006.00503.x

8. Coccorese, P. (2009). Market power in local banking monopolies. Journal of Banking and Finance, 33 (7), 1196-1210. http://dx.doi.org/10.1016/j.jbankfin.2008.12.013

9. Demirguc-Kunt, A. \& Peria, M.S.M. (2010). A Framework for Analyzing Competition in the Banking Sector: An Application to the Case of Jordan. Policy Research working paper No. 5499, $1-24$.

10. Fernandez De Guevara, J., Maudos, J. \& Perez, F. (2005). Market Power in European Banking Sectors. Journal of Financial Services Research, 27 (2), 109-137. http://dx.doi.org/10.1007/ s10693-005-6665-z

11. Fungáčová, Z., Solanko, L. \& Weill, L. (2010). Market power in the Russian banking industry. Bank of Finland Discussion Papers No. 3, 1-27.

12. Chan, D., Schumacher, D. \& Tripe, D. (2007). Bank Competition in New Zealand and Australia. In Centre for Financial Studies Banking and Finance Conference. Melbourne, September 2007.

13. Lerner, A.P. (1934). The Concept of Monopoly and the Measurement of Monopoly Power. The Review of Economic Studies, 1 (3), 157-175. http://dx.doi.org/10.2307/2967480

14. Panzar, J.C. \& Rosse, J.N. (1987). Testing for 'Monopoly' Equilibrium. Journal of Industrial Economics, 35 (4), 443-456. http://dx.doi.org/10.2307/2098582

15. Pruteanu-Podpiera, A., Weill, L. \& Schobert, F. (2007). Market Power and Efficiency in the Czech Banking Sector. CNB Working Paper No. 6.

16. Rojas, Ch. (2011). Market Power and the Lerner Index: A Classroom Experiment. Forthcoming, Journal of Industrial Organization Educatio, 5, (1), 1-19. http://dx.doi.org/10.2202/19355041.1033

17. Staikouras, Ch. \& Koutsomanoli-Fillipaki, N. (2006). Competition and concentration in the New European banking Landscape. European Financial Management, 12 (3), 443-482. http:// dx.doi.org/10.1111/j.1354-7798.2006.00327.x

\section{Contact information}

Ing. Iveta Repková

Silesian University in Opava, School of Business Administration in Karviná

Univerzitni námèstí 1934/3, 73340 Karviná

Tel: +420596398406

E-mail:repkova@opf.slu.cz.

JEL Classification: G21 